\title{
Recognition for Convenience! Kenya's Foreign Policy towards South Africa under Moi's Era (1978-1998)
}

\author{
D. O. Mabeya
}

\section{ABSTRACT}

During the 1970s, majority of states, including Kenya followed the practice of recognizing states and not governments. In so doing, they downplayed the granting of formal recognition to new governments. Kenya's policy, then, was clearly stated in parliament in 1971 when the then foreign affairs minister, Dr. Njoroge Mungai, was asked to comment on the Kenya government's position on the military regime of General Idi Amin of Uganda. He stated, "Kenya could not afford to interfere with internal matters of another state nor let any state interfere with internal matters of Kenya." However, during the Post-Cold War period, Kenya's recognition policy underwent major transformations to include recognition of de jure governments. This study critically examines Kenya's recognition of South Africa government during and after the Cold War in a bid to reveal any distinct policy trends if any during Moi's era. The study aims to ascertain how, Kenya's recognition policy, has largely, been formulated, articulated and exercised during Moi's administration (1978-1998). The central question of this study is this: What recognition trends emerged towards South African government under Moi's administration (1978-1990)?

Keywords: Foreign Policy, Governments, Legitimacy, Recognition, States
Published Online: December 15, 2021

ISSN: $2736-5522$

DOI: 10.24018 / ejsocial.2021.1.6.2021

\section{O. Mabeya}

Southeast Community College, Lincoln, Nebraska, USA

(e-mail: danvasm ${ }^{@}$ yahoo.com)

\section{INTRODUCTION}

Kenya's policy was clearly stated in parliament in 1971 when the then Foreign Affairs minister, Dr. Njoroge Mungai, was asked to comment on the Kenyan government's position on the military junta of General Idi Amin of Uganda. He announced Kenya's doctrine of recognizing effective governments rather than regimes. Thus, this made the Kenyan government recognize Idi Amin's government as an effective government rather than that of Milton Obote (Munene, 1997). During the cold war, Kenya, like many other states, adopted the Estrada Doctrine on recognition. The Estrada Doctrine pre-supposes the automatic recognition of governments in all circumstances (Jessup, 1931). It attempts to lay down a clean test for recognition in all circumstances excluding political considerations and exigencies of State and is thus unrealistic, particularly where there are competing governments. It has been criticized as minimizing the distinction between recognition and maintenance of diplomatic relations. However, a complete opposite fashion of this is the Tobar Doctrine or the Doctrine of Legitimacy (Stansifer, 1967, pp. 251-272), which suggests that, governments which came into power by extra-constitutional means should not be recognized, at least until the change had been accepted by the people. The concept amounts to the promotion of nonrecognition in all revolutionary situations and it is, and was, difficult to reconcile with reality and political consideration (Mexican secretary of Foreign Relations).

\section{BRIEF HISTORY OF DANIEL TOROITICH ARAP MOI}

Daniel Toroitich arap Moi is the second President of Kenya. He took over power after the death of Jomo Kenyatta who was the first President of Kenya. During Kenyatta's death, Moi was serving as Kenya's vice President and the constitution paved the way for Moi's succession after Kenyatta died. Moi was born on 2 September 1924 in Kuriengwo then a Kenya Colony located in the Sacho locality in Baringo district (now county) (McKenna, 2020). He belonged to the larger community of the Tugen sub-group of the Kalenjin community that reside in the Kenyan Rift Valley. Moi died on 4 February 2020 (East \& Richard, 2014). Moi is considered a statesman and shrewd politician who served as the second and longest Kenyan Presidency (1978 to 2002) after the death of the founding father President Jomo Kenyatta who died on August 22, 1978. Before that, Moi had served as the third Kenyan vice President (1967 to 1978) after 
Jaramogi Oginga Odinga.

On 1 August 1982, Air Force personnel, led by Senior Private Grade-I Hezekiah Ochuka and backed by university students, attempted a coup d'état to oust Moi. However, the coup was quickly suppressed by military and police forces commanded under the command of the then Chief of General Staff Mohamoud Mohamed (Nyamora, 1992, p. 12). The main conspirators of the coup, including Ochuka were sentenced to death. This marked the last judicial known executions in Kenya (Ndunda, 2016).

Moi's continuation of Kenyatta's pro-Western policies ensured significant sums of development aid during the Cold War (1947-91) making Kenya one of the most prosperous African nations. In the early 1990s, however, Moi's regime faced the end of the Cold War, an economic stagnation under rising oil prices and falling prices for agricultural commodities especially in Africa. At the same time with the end of the Cold War in the 90s, the West no longer dealt with Kenya as it had in the past, as a strategic regional stronghold against communist influences from Ethiopia and Tanzania.

After independence in 1963, Kenya remained a one political party state till the late 1990s when ironically, Western countries began to demand political and economic reforms. The push led Moi to legalize opposition parties in 1991. Moi announced his intention to repeal Section 2(A) of the constitution, allowing multipartyism through a KANU conference in Kasarani in December 1991. Despite fierce debate and opposition from many delegates, the conference eventually passed the motion unanimously (Throup \& Hornsby, 1998).

Moi ran for re-election and won elections in 1992, the country's first multiparty elections amid charges of electoral fraud and riots. Again, a similar situation was witnessed in 1997 elections, where hundreds of Kenyans, mainly Kikuyu, were killed though Moi was elected again to his fifth term as president. However, Moi was constitutionally barred from running in the 2002 presidential elections. Some of his supporters floated the idea of amending the constitution to allow him to run for a third term, but Moi preferred to retire, choosing Uhuru Kenyatta, the son of Kenya's first president, as his successor (Lacey, 2002). KANU split into two, with dissidents joining the National Rainbow Coalition, whose candidate, Mwai Kibaki. A two to one majority elected Kibaki president over Kenyatta, and was confirmed as president on 29 December 2002. Moi handed over power in a chaotic ceremony that had one of the largest crowds ever seen in Nairobi in attendance. The crowd was openly hostile to Moi (Lacey, 2002).

After leaving office in December 2002 Moi was largely shunned by the political establishment though he retained some popularity with the masses. His presence in public places show a gathering or a huge crowd. In 25 July 2007, President Kibaki decided to appoint Moi as a special peace envoy to Sudan, referring to Moi's "vast experience and knowledge of African affairs" and "his stature as an elder statesman" bringing him to limelight again. In his capacity as peace envoy, Moi's Moi was to help secure peace in southern Sudan, where an agreement, signed in early 2005, was being implemented (Hull, 2007).

In August 2017, Moi was diagnosed with dementia (Kahawatungu, 2017). And in October 2019, he was hospitalized under critical condition at The Nairobi Hospital due to complications of pleural effusion (Mphaso, 2019). Moi died at The Nairobi Hospital on the early morning of 4 February 2020, at the age of 95 though his son, Raymond Moi, disputed that age claiming his father died aged at least 105 years (Standard Digital, 2020). A state funeral was held at Nyayo Stadium on 11 February 2020, followed by his burial at his Karabak home in Nakuru county on 12 February 2020 (BBC News, 2020). The funeral was done with complete military honors that included a 19-gun salute followed by a missing man formation flyby (Moi sent off with 19-gun salute-VIDEO, 2020). He was buried next to his former wife Lena Bomett (BBC News, 2020).

\section{JUSTIFICATION AND OBJECTIVE OF THE STUDY}

Not much was written about Kenya's foreign policy during Moi's reign especially towards South Africa. Foreign policy was in Moi's roadside speeches rather than documented. Scholars have doubted Kenya had stated foreign policy during Moi's reign. The objective of this study is to show how Kenya recognized governments in the period 1978-90 during Moi's term in office as president. It was in this period that there were rapid changes of governments around the world but more especially in Africa. Once an international actor (State) has been accepted internationally, it becomes very difficult for other international actors to change the status from recognition to non-recognition because of overthrow or any other change of government. The State remained an international legal person. Therefore, change of government did not affect the identity of the State as it was. Recognition of a government then means recognition of the State, but did not work the other way (Talmon, 1988, p. 309). What was challenging was the international community could not just assume recognition of new governments asserting themselves constitutionally or unconstitutionally with belligerent administrations in areas formerly controlled by legitimate governments. The implication of having international recognition was to have the ability to conclude treaties, seeking membership into the international organizations like the United Nations and to have a vote to make 
decisions in the organization (Article 1 of Montevideo Convention on Rights and Duties of States 1933) (Dixon \& McCorquodale, 1991, p. 127).

\section{The United StATES}

In 1793 the U.S secretary of state Thomas Jefferson, for instance enunciated the classic American position, "we surely cannot deny to any Nation that right where on our own government is founded, that everyone may govern itself according to whatever form it pleases, and change these forms at its own will, and that it may transact its own business with foreign Nations through whatever organ it thinks proper. Whatever King, convention, assembly, committee, president or anything else it may choose, the will of the Nation is the only thing essential to be regarded" (Jentleson \& Paterson, 1997, pp. 466-467). The reason for having diplomatic relations was not to confer a compliment, but to secure a convenience.

The U.S recognition policy first stated that to be recognized, a government had to show respect for its international obligations. Nevertheless, in 1913 President Woodrow Wilson dealing with governments of Latin America introduced a new principle. The government must have been established through constitutional procedures respecting the will of the people. He used the withholding of recognition as a weapon against those who did not meet these standards (Withheld diplomatic recognition from the Soviet Union for sixteen years) (Jentleson \& Paterson. 1997, p. 467).

\section{RESEARCH PARAMETERS}

This study focuses on Moi's foreign policy towards South Africa during and after the cold war (19781998). Kenya's policy on recognition of governments during Moi's administration was not clear. The mystery, which surrounded the formulation and articulation of this policy, and the personalities who had been concerned lead to the question as to whether Kenya did have a recognition policy. This research investigates the nuts and bolts of formulation, trends and articulation of Kenya's recognition policy during Moi's term in office with a case of South Africa. The central question investigated in this study is this: What recognition trends emerged towards the South African government under Moi's administration (19781990)?

\section{IMPORTANCE OF THIS STUDY}

The intended destiny of the study is to assist scholars and the public, to discern and understand the trends and articulation of Kenya's recognition policy under Moi's administration towards South Africa. The outcome of the study is intended to be beneficial to scholars who want to carry out further research into Kenya's recognition policy towards South Africa and Moi as a case study. On the other hand, the study is intended to be a revelation into the most crucial but difficult component of Kenya's foreign and recognition policy. At the end, recognition policy trends and articulation towards South Africa would have been partially if not fully answered. Scholars who are currently studying Kenya's recognition policy towards South Africa can reference this study as a bedrock to identify consistencies, continuity, or discontinuity of Kenya's foreign policy with preceding administrations after Moi.

\section{CONCEPTUAL FRAMEWORK}

Recognition is thought to be fundamental in international law. Through recognition, international rights and obligations shall or shall not be put against new states or governments. It concerns also the rights and duties as an obligation to a community or not. The life of a state rotates around recognition. It is the starting point of the State or government as the legal personality. It is composed of subjects of international law. Recognition itself is serious and complex in its nature. And at times is subject to abuse by various governments (Taylor, 1994, p. 25). More serious is the question of those states that are not represented at the United Nations Organization as they are subject to non-recognition by major powers and international actors. This is because these major powers have the manipulation capacity to approve who is to be accepted into the organization or not because of the veto power. Therefore, "recognition" can be said to mean the act of acknowledging the fact of existence of a new entity into the international system and according it an independent status in existing international order, with rights and duties as envisaged in the international legal document (Satyavrata, 1964, p. 45).

Recognition of a new government arises when the State as an international actor remains, but the government in power is totally overthrown by either a revolution or by a popular uprising and that the State power is transferred to another entity or rebels in this case (Malcolm, 1997, p. 306). The difficulty which 
arises in such circumstances is that once such a government is not recognized, that might also mean that the State is not recognized because it is that government that represents the State. Accordingly, then, a new entity (State) can be recognized through formal declaration, accepting of the recognized State to enter into legal relations with the recognized entity or by issuing a formal statement or by conduct of the State concerned. Therefore, recognition conforming in accordance to international law (Satyavrata, 1964, p. 45). Professor Hyde in Moore and Rivier, defines recognition as "the assurance given to the new State (if the State is the subject of recognition) that will be permitted to hold its place and rank in the character of an independent political organism in the society of nations" (International Law I. 56). This however relates only so far as the international legal personality of a State is concerned. Accordingly, then, a new entity (State) can be recognized through formal declaration, accepting of the recognized State to enter legal relations with the recognized entity or by issuing a formal statement or by conduct of the State concerned. Therefore, recognition is conforming in accordance to international law (Satyavrata, 1964, p. 46).

\section{ORGANIZATION OF AFRICAN UNITY (OAU)}

Kenya's recognition policy as envisaged in the foreign policy has over time, since independence changed with time. This is due to changing circumstances in the dynamic world. After independence, Kenya became a member of the OAU. So, in essence, Kenya subscribed to the OAU charter, which in part wanted member countries to contribute to a fund meant to assist those countries, which had not attained their independence, do so through a liberation struggle. It was in this spirit that recognition was only focused on those states that had attained their independence from the colonialists. Eventually these were also the States that could join the OAU as its charter stipulated. These states could then join the United Nations thus becoming international actors.

However, the independence celebrations were short lived to most of these African countries. It dawned earlier than later, that the states, which had just acquired independence, were falling victim to coups. The military started ruling in several new states. This posed a new challenge both to the OAU and to regional governments. What then emerged immediately was for the OAU to change strategy. A way was to be devised to solve this emerging trend. A conflict management department was formed to look into this new challenge. However, the number of states that were ruled through extra-constitutional ways increased and the OAU was overwhelmed. Here the question of recognition of such regimes was arising with the fear that by recognizing such regimes could give motivation to other States also to follow suit. Many, including Kenya decided to stick to their guns, by only recognizing states and not governments. It is easy to realize here that recognizing only States has its own problems. First, those states that are not recognized suffer from being isolated from the international community. Second, those states that refuse to offer recognition also risk carrying out bilateral trade with such states, which could be having crucial resources needed by the non-recognizing state. Then the third is the idea of national interest of the non-recognizing state. What will be at stake from such action?

Moi came to power at the height of this confusion. However, Kenya tried to maintain its policy on noninterference in other country's internal affairs. It is in this context that Kenya managed to relate to military regimes, more especially to the brutal regime of Idi Amin of Uganda. Only four years later, in 1981, Moi was to become the OAU chairman. Amongst his first challenges was to deal with conflicts in Chad, Western Sahara, apartheid South Africa, Namibia, Sudan, Angola and Mozambique. Ironically as Moi was trying to get solutions to conflicts elsewhere in Africa, back home things were also getting out of hand. In 1982, the Kenya air force staged an unsuccessful coup (Nyamora, 1992, p. 12). This really put Moi on an awkward position as a peacemaker.

\section{LITERATURE REVIEW}

\section{A. How Mois's Foreign Policy Emerged 1978-1998}

After the death of the founding father of the republic of Kenya President Kenyatta on August 22, 1978, Moi took office as the second president. Though he tried to follow the footsteps (Nyayo philosophy) of his predecessor, he from time to time shifted his recognition policy of governments to go in line with changing times both domestically and internationally. The most visible aspect in the continuity of Kenya's recognition policy from Kenyatta to Moi in the 1980s was Kenya's continued alliance with socialist Ethiopia, as long as the Somalia threat remained, there were no compelling reasons to withdraw from the pact. While the foreign policy making process under Kenyatta was extremely cautious, with State house only giving final clearance for the pursuit of foreign policy. Under Moi foreign policy making was differentiated by the president's personal diplomacy and involvement in the management of foreign policy sometimes to the exclusion of relevant institutions to the foreign policy making process. Secondly, Kenya's foreign policy had been both constrained and determined by the country's economic performance, and 
internal opposition to the Moi regime. As the region shifted towards a new regional equilibrium, particularly with resolution of conflict in Ethiopia, the dangers of regional instability caused by ethnic sub-nationalism in Sudan, Uganda, Rwanda, Burundi and the Democratic Republic of Congo, Kenya's recognition policy of governments had to take cognizance of the need to mediate internal conflicts in the region.

\section{Moi as the Chief Architect of KenyA’s Foreign Policy}

Musambayi (1995) suggests that Moi over time not only cherished summits but equally exposed foreign policy statements in many political rallies he addressed. This to him, is totally a complete shift from his predecessor (late President Kenyatta) whose practice of leaving foreign policy and articulation to those under him. Eventually as Moi led the foreign policy formulation and articulation, he moved foreign policy from its office along Harambee Avenue to the office of the president at Harambee House. In the process he ended up personalizing the foreign policy. The late minister for foreign affairs Dr. Robert Ouko acknowledged this by saying that, "the chief architect of Kenya's foreign policy was President Moi" (Chelagat, 1991). Foreign policy being complex, leaving it to one person can be very taxing. This led Kenya in most cases to fall victim to being an advocate of principle rather than commitment. All shortcomings in Kenya's foreign policy can be attributed to one-man style of doing things or rather a clique who might not be having the interests of Kenyans at heart. The Democratic Republic of Congo is one example where Kenya shifted its foreign policy overnight. It was to be in the interest of all Kenyans if the public and parliament debated foreign policy before being implemented since it involved the country's national interests.

\section{Influential Personalities in Foreign POLICY}

During Kenyatta's era, it was difficult to talk about Kenya's Foreign policy without giving reference to personalities like, James Gichuru, Njoroge Mungai, Peter Mbiyu Koinange, Joseph Murumbi and Charles Mugane Njonjo. Foreign policy formulation was a preserve of Dr. Njoroge Mungai, Charles Njonjo and Mbiyu Koinange notwithstanding the fact that Murumbi oversaw that slot as minister of foreign affairs. Even after Kenyatta's death in 1978, Njonjo who was the Attorney General during Kenyatta's era remained in government in the new government of Moi in the same position as before. Infact, he had helped Moi secure the presidency after the Kikuyu elites wanted to block Moi's succession bid according to the Kenyan constitution. By blocking him by changing the constitution through parliament. He still remained very powerful though most of his colleagues in the Kenyatta government started falling off. It is to be remembered that during Kenyatta's era, Njonjo had tried openly to change the recognition policy of Kenya, by urging the government to change its policy of non-recognition to recognition of the Boer regime of South Africa. But the then foreign affairs minister, Mr. Munyua Waiyaki replied that, "it would only happen over his dead body (Munene, 1997). So, Kenya did not recognize the Boer regime of South Africa although unofficial dealings still went on. Njonjo wielded a lot of power; even the criminal investigation department came directly under him. As Attorney General, from independence to 1980 when he resigned to enter politics, Njonjo had even had a lot of influence as to who was appointed to the judiciary. He as the then Attorney General spearheaded the smooth transition from the late President Kenyatta to Moi in 1978 (Weekly Review, 1983, p. 4). It thought that, Njonjo had stood the way of growth of the office of the Attorney General that when he left, "the man and the office became so identical that when Njonjo left, the country had a difficult time adjusting to his departure (Weekly Review, 1983, p. 4). During Moi's era, Njonjo's influence could be felt everywhere, in and out of the country. Njonjo was too close to Moi. The public could even see it. In neighboring countries, the first former president of Tanzania feared him, as a powerful capitalist. But with his downfall in 1983, after he was named a traitor following the August 1982 coup, Kenya underwent another transition though less from that of Kenyatta to Moi. This one was from "Njonjo era to post Njonjo era (Weekly Review, 1983, p. 4).

The person who took over from Njonjo's position as the second most powerful person other than the president in Kenya was Mr. Nicholas Kipyatur Kiprono arap Biwott. Biwott was the president's trusted key adviser and strategist, his confidant and business associate. so much is his influence that he earns the nickname he gave himself as "Total Man (Weekly Review, 1993, p. 21). Though a powerful minister, Biwott's life was surrounded with alleged mystery, scandals and corruption. It was rumored that he masterminded the killing of the then foreign affairs of Dr. Robert Ouko.

In February 1990, the then minister for foreign affairs and international cooperation, Dr. Robert Ouko died in mysterious circumstances. His body was found burnt six kilometers away from his Koru home after missing for about three days. Moi said in a statement after learning of his death, "It is with profound sorrow that I have to announce today the death of honorable Dr. Robert Ouko, minister for foreign affairs and international cooperation and Member of Parliament for Kisumu town. Dr Ouko is the best foreign minister 
that Kenya has ever had. I will greatly miss him (Weekly Review, 1990, p. 5). Dr. Ouko had just flown home from the US after attending an American Annual congressional breakfast prayer meeting in Washington D.C with President Moi. After learning of his death, the US embassy in Nairobi flew its flags at half-mast for two days which was very unusual for a foreign country to honor an individual who was not a head of State while the Kenyan government did not.

\section{KENYA - COLD WAR ERA (1978-1990).}

During this period, several issues shaped Kenya's recognition and non-recognition practice as tools of foreign policy practice. Amongst these were the ideological, geographical and strategic rivalries amongst the super-powers. Europe was divided into armed camps whereas the other parts of the world were placed under security alliances with some remaining non-aligned. All these developments led to the continents of Asia, Latin America and even Africa to forge forward for the Estrada Doctrine (Jessup, 1931), which generally accepted governments as they came and needed international attention. Recognition of States only was the order of the day in the 1970's while granting or withholding recognition to new governments was overlooked.

\section{KENYA-SOUTH AFRICA}

Economic interests accompanied Kenya's recognition policy towards the South. It was thought that Kenya was one of those countries that were spearheading the freedom of South Africa from the hands of apartheid in the Pan-African movement as proclaimed under the Organization of African Unity. However, the revelation that Kenya had secret dealings with the South African apartheid government, dented its name in Africa and more especially amongst those liberation movements fighting to end the apartheid regime. The then minister for foreign affairs, Mr. Elijah Mwangale denied on behalf of the Kenyan government that there ever was such a deal. A London magazine (Africa now) had published a report implicating the Kenyan government of having allowed the then South African foreign minister "Pik" Botha to visit Kenya. Mwangale said that Kenya was composed of Nationalists and could not allow that to happen. He insisted that, the Kenyan foreign policy had been very consistent and no contact whatsoever had been made with racist South Africa, not then nor in the future till apartheid was dismantled. In another publication, published in South Africa (South African Panorama, October, 1984 issue), there were Kenyan students studying at the Medical University of South Africa (Medusa), 30 kilometers northwest of Pretoria. In his reply, the minister said, the report was "a lot of rubbish". 53 What emerges here, is consistency in Kenya's foreign policy towards South Africa though covertly from Kenyatta's regime to Moi's. Retrospectively during Kenyatta's time, the government had trade links with South Africa. Indeed, this was openly said by the then second vice-President (Murumbi), when he said "I have no qualms at all, trade must go on, my opinion as a businessman is that business must be promoted and I am concerned only with the interests of this country." Murumbi made this statement when he was appointed as chairman of a cigarette company started by Rothmans of South Africa on a 50-50 basis. This gave the government's position towards South Africa, though Kenya had adopted OAU's resolutions CIAS/Plen 2/ Res 2 of May 1963 and CM/Rs (II) of June 1964 that called on all OAU member states to impose sanctions on South Africa.55 Though Kenya openly denounced the apartheid regime and giving her contributions to the OAUs liberation committee, her real foreign policy to the South African apartheid regime was that of cooperation. Kenya even refused to grant training facilities and bases to liberation groups from South Africa. Under Moi, in international conferences, Kenya was not only opposed but also abstained from voting on important OAU resolutions which were meant to bar South Africa's, sea, air and other communication links from going through their territories. Kenya allowed and benefited from airlines bound for South Africa to use its air space and air facilities in Nairobi. What is interesting here, is that this trade was not actually for the benefit of all Kenyans, but was a preserve of a few elites in the center of power. They not only imported luxurious cars, but also imported foodstuffs, which were sold in the Kenyan supermarkets. Kenya also exported to South Africa tea and coffee. South African tourists continued to come to Kenya until 1983 when the Kenyan government thought that the South African apartheid regime wanted to assist Njonjo to overthrow Moi's government.

To put things straight, the Njonjo affair did not shake the relationship between the two countries as trade continued. Also, to add weight to this, Moi was the first African president to step on African soil after Kamuzu Banda of Malawi in 1978. As a rejoinder to this, Moi hosted De Klerk in Nairobi in 1991.56 All this had a negative impact on Kenya, more especially from liberation organizations, like the African National Congress (ANC) who were really unhappy with Moi's actions. ANC went further to cancel talks between its president and Moi after he had praised De Klerk's reforms. In a statement issued by the ANC spokesman in 1990, it said,

We would prefer to see Kenya maintain sanctions against South Africa...we are extremely 
saddened by Kenya's move over the years which had shown extreme insensitivity to aspirations of the African people ... a situation which forced Mandela to cut out of Kenya itinerary on various occasions. It is regrettable that when the momentum of real progress has just begun it is brotherly African States like Kenya and Zaire who for obvious financial gain after years of court ship by Pretoria that are compromising gains so far made. While majority South African government will be too preoccupied with rebuilding a nonracial South Africa, it will be an allusion to expect a redcarpet welcome for countries that have in one way or another been insensitive to the feeling of the black people in South Africa (ANC Spokesman, Finance November 1990).

Kenya's foreign policy towards South Africa was two-fold in the 1980s. On one hand, Kenya was more interested in her national interests in South Africa than in economic gains. Since many countries had placed trade sanctions against the apartheid regime, Kenya saw an opportunity to exploit covertly. On the other hand, overtly Kenya was fighting hard at the international forums against the apartheid regime. In 1986, Kenya signed the international convention against apartheid in sports, it was among the forty-three countries that also signed and this was later adopted by the United Nations general assembly, although there were no western countries that signed for the same. This was a way of isolating South Africa from participating in the commonwealth games in Edinburgh, Scotland in 1986 (Weekly Review, 1986, p. 38). In another conference held at Denver, Colorado, USA in 1986, Kenya led other African countries to press for isolation of the South African apartheid regime. The Kenyan delegation attending the first world livestock producer's conference walked out just before the meeting began in protest against the presence of a South African delegation. Kenya later was to become one of the most vocal African country in condemning apartheid, and President Moi could not finish his speeches in any national day without reminding Kenyans of the struggle for human dignity being waged in South Africa (Weekly Review, 1986, p. 14)

The South Africa apartheid regime having known the Kenyan unfriendly stand against it, it also never wasted time to pay back. Though South Africa is far away from Kenya, an opportunity came at hand when the Kenyan forces were sent to Namibia as part of the United Nations Transitional Assistance Group (UNTAG). It did not take long after the Kenyan forces had arrived in Namibia that they came under attack from the South African forces in Namibia. It was reported by the minister for foreign affairs and international co-operation Dr. Robert Ouko, that South African forces had launched a grenade and machine gun attack on the military base of the 850-strong Kenyan UNTAG contingent at Outjo. But the South African press claimed that the Kenyan forces were contravening the aims and objectives of the United Nations regulations for Namibian independence, scheduled that year (1989). However, the United Nations investigators defended the Kenyan forces by saying that they were highly disciplined. It was also apparent to the South African apartheid government that, Kenya had been supporting Namibian independence by agitating for the removal of South African forces from Namibia. Kenya supported (SWAPO) by even allowing the organization to open offices in Nairobi and letting its leader Sam Nujoma be a frequent visitor to Nairobi. SWAPO (South African People's Organization) had been fighting the South African forces in Namibia from their bases at neighboring Angola (Weekly Review, 1989, pp. 14-15). After independence, elections were held and Mr. Sam Nujoma was elected head of State. Moi acknowledged the election of Mr. Nujoma as president elect of the republic of Namibia by attending the Independence Day celebrations.

\section{KenYA - SOUTH AFrICA POST-COLD WAR ERA (1990-98)}

While changes were already taking place in the self-proclaimed Marxist-Leninist regimes in Africa following the collapse of the Soviet Union over Eastern Europe and the rest of the world. The tone of change for 1990 maybe said to have been set by a little-known conference in Arusha, entitled, "The International Conference on People's Participation." Sponsored by the UN (Weekly Review, 1990, p. 38). The warning was timely as, some three decades ago, the British Prime Minister Mr. (later sir) Harold Macmillan declared that the wind of change "was blowing over the African continent in reference to the end of colonialism.

In 1990 after 30 years, a second wind of change was blowing over Africa, shaking political systems that were established by many African countries soon after independence (Weekly Review, 1990, pp. 11-14). With the collapse of the Soviet Union and communism, the cold war rivalry ended between the East and West. Simultaneously, those countries that had strategic importance to the West lost it. Instead, the west started attaching conditionalities to any aid given. Amongst those countries affected most was Kenya because it depended on assistance from western donors. While addressing a conference on Africa's finance and development crisis in 1990 in Washington, the then US assistant secretary of State for African affairs, Mr. Herman Cohen acknowledged that political changes like the introduction of multi-party systems in Africa were becoming a priority concern of the African government. An influential figure in congress, the senate's republican leader, Mr. Robert Dole, who was a 1988 presidential aspirant, went on record for 
supporting the aid-for-multi-parties' conditionality. Later repeated by the US assistant secretary of State Mr. Cohen Herman (Weekly Review, 1990, p. 14). As the idea of multi-partism emerged and many African countries including Kenya were not ready to embrace this. Moi was feeling very uneasy. He declared that multi-party systems were unsuitable for Africa, at the moment. "as they were likely to breed tribal alliances and that would bring chaos" (Weekly Review, 1990, p. 11). In 1990 the then US ambassador to Kenya Mr. Smith Hempstone was very vocal in asserting the merits of a multi-party system, a fact which angered some local leaders and surprised some in diplomatic circles (Weekly Review, 1990, p. 13).

\section{ForeIGN AID}

As a way to force the Kenyan government to make reforms and adopt multi-partism, the US government froze aid to Kenya. With a tight economic situation and since the cold war was over and no East to turn to for financial assistance, Kenya had to look for new friends. One of those countries that readily accepted to assist Kenya was South Africa. Kenya granted South Africa premature recognition in spite of sanctions imposed on that country. Bilateral trade was started though at a small scale. South African airways started flights to Kenya in December 1990. This was after President Moi and South African foreign minister Mr. Roel of "Pik" Botha met in Nairobi. This was a major go-ahead of a re- establishment of trade links and full diplomatic ties between the two countries. That meant that the Kenyan government recognized the antiapartheid reforms made by that time by the South African government and President Fredrick De Klerk. However, according to the minister for foreign affairs and international co-operation by then Mr. Ndolo Ayah, the official policy towards South Africa still remained and this confirmed that the government had made a premature recognition (Weekly Review, 1990, pp. 6-7). In 1976, the then powerful Kenyan Attorney-General Mr. Charles Njonjo suggested that Kenya establish formal links with South Africa. "over my dead body (Weekly Review, 1991). The then minister for foreign affairs, Dr. Munyua Waiyaki had said. In 1991 June, the then South African President, Mr. Wilhem de Klerk, became the first leader of the white minority regime to pay an official visit to Kenya. He held talks with President Moi concerning bilateral trade between the two countries and in sports. An OAU summit held at that time had just passed resolutions allowing formal and informal contacts between independent African countries and South Africa by adopting a moderate and pragmatic resolution on continued sanctions against the apartheid regime. Nelson Mandela had objected to any country that tried to have links with South Africa's apartheid regime until a consensus had been reached to abolish apartheid and free and fair elections held. By this time Kenya had already tried to amend relations with South Africa.

The road to free and fair elections was not easy. As the white minority tried to push President de Klerk not to accept reforms. There was a lot of violence from different freedom fighting groups more especially from the Inkatha Freedom Party (IFP) as the country was preparing to go the first all-race elections. Inkatha, under their leader Buthelezi had objected to some election procedures and had threatened to boycott the elections. A Kenyan Professor, Washington Jalango Okumu in 1994, brokered a deal, which ended the boycott by the Inkatha Freedom Party (IFP). Professor Jalango, a Professor of economics who was by the then Ford Kenya's "ambassador-at-large," had voluntarily remained behind when other international mediators in the South African impasse, led by the former American Secretary of State, Dr. Henry Kissinger, and former British Foreign Secretary Lord Carrington, had given them up. Ironically, Okumu was a student of Kissinger at the prestigious Harvard University in the United States during the 1960's. It was confirmed by Buthelezi, that it was due to Okumu's personal intervention that brought about the breakthrough. As a result of which "South Africa might well have been saved from disastrous consequences of unimaginable proportions" (Weekly Review (Nairobi), 1994, p. 34). Okumu drafted the proposals agreed by the parties.

Nelson Mandela won the South Africa all race first election by a majority of $62.3 \%$, under the ticket of African National Congress (ANC). Mandela and his party won by a two-thirds majority. Anything less than $60 \%$ could have been considered as a failure for the ANC (Weekly Review (Nairobi), 1994, pp. 31-35). President Moi attended Mandela's inauguration ceremony amongst other African leaders in 1994 as a sign of recognition of the new South African government (Weekly Review (Nairobi), 1994, p. 30). Since then South Africa has played a key role in conflict resolution in Africa and in bilateral trade amongst African countries. Though friction continued between (ANC) of Mandela and (IFP) of Mangosuthu Buthelezi, in the mid-1996, owing in part to mediation by the then vice-President Thabo Mbeki, relations between the ANC and IFP subsequently improved. Buthelezi, who was then minister of home affairs, abandoned his demands for devolution for Kwa Zulu/Natal and no longer insisted that the matter of provincial powers be referred to international mediation. Due to this, Mandela made a rare and surprising move which many presidents in Africa never do by inviting Buthelezi to be acting President on a number of occasions when, he, Mandela was on mission out of the country (Regional Surveys of the World, 1999, p .1003). 


\section{Methodology}

This study focuses on Moi's foreign policy 1978-1998. The research materials for this study were mostly from secondary sources, though with a few personal statements from willing people I contacted at the ministry of foreign affairs and the Nation newspapers. Mainly the information gathered was from Magazines, Weekly's, Newspapers, Books and Journals.

\section{ANALYSIS}

Due to the information collected, the method of analysis used in this study was descriptive and analytical. Various studies, speeches, statements, books, newspapers, magazines, seminar papers and research papers were closely examined (analyzed). In addition, case studies were given.

\section{LIMITATIONS}

Though I tried as much as I could not to be biased on my arguments and critique, at times I felt overwhelmed by issues that I found myself so strongly against certain personalities. Time was also a factor which was confined. Places I visited like the foreign affairs offices and the people I interviewed were rather unwilling to delve into critical issues concerning the government and more especially President Moi.

\section{Analysis of This Study: Recognition Policy Rationale}

As noted earlier, Kenya, like most States, adopted the policy of recognizing States only under Moi. This was in pursuit of avoiding antagonism brought about by recognition of governments. In this circumstance then, Kenya was able to overtly recognize governments which otherwise it could have not (Galloway, op. cit, p. 142). In the formative years it was difficult to identify the direction of Kenya's recognition policy due to the non-existence of any identifiable tradition or established pattern of interests, however John Howell (1968) identified two strands, one conservative and the other radical in Kenya's foreign policy, thus seeing two distinct strands in Kenya's international relations. The conservative policy operated with respect to Kenya's objectives in Eastern Africa-objectives, which revolved around maintaining the regional status quo of pre-independence, which facilitated and enhanced Kenya's predominant role in the region. Secondly, the radical strand in the international arena characterized by non-alignment in international affairs as a principle by which the new State asserted its independence and sovereignty although Kenya covertly had dealings with the South African regime. Though it was clear that the principle of non-alignment presupposed that Kenya envisaged the principle of self-determination, which also pre-supposes that a State should refrain from interfering in internal matters of another State. This gives reference to respect for territorial integrity of other States. A principle found in OAU and UN charters (Olatunda, 1985, p. 87).

\section{CONCLUSION}

Kenya's foreign policy during the cold war towards South Africa was at best confusing and not articulated well. Thus, it was limited to foreign policy of convenience and mostly served Kenya's economic interests while South Africa was searching for international recognition. The study has surveyed Kenya's recognition policy under Moi's regime towards South Africa with reference to International Law. The issue of legitimacy of governments has been examined. The justification of recognition has also been dealt with in reference to the situation, national interest and period (Cold War and Post-Cold War era). The change in recognition policy from that of States to governments has also been surveyed and the reasons why have been stipulated. Regional diplomatic change and the need for Kenya to avoid isolation in the changing world have been traced. The study also gave the theoretical framework under which my arguments were based. The importance of this study has also been explained. An in-depth analysis of Kenya's recognition policy and critique of the emerging policy is also highlighted, given the dynamic regional and international policy realities have been looked into that influenced foreign policy towards South Africa. What is then important in the change in Kenya's recognition policy is that it gave Kenya a new look into regional and international affairs. In a wider perspective, it helped shape Kenya's foreign policy in a new dynamic and yet the public and parliament, not even the foreign ministry, was directly involved. It is true that any foreign policy of any country ought to be based on realities and not on hearsay. It should be focused on long term rather than short-term objectives. This will help foreign policy have formulation trends and articulation patterns. Then with a well-stipulated, framed and balanced foreign policy, Kenya can move into the next stage, which will be claiming regional and international Leadership. 
My recommendation would be, for contemporary Kenya to have a vibrant foreign policy, it would be important to have all stakeholders involved in the formulation of foreign policy. The public should be left to have an input, the legislature and the intellectuals must have a role to play for Kenya to have a vibrant foreign policy. Higher learning institutions should be the pillars at which foreign policy is not only learnt but also debated and tested as compared to foreign policies of other countries. In this way, new life will be pumped into the already nearly dormant foreign affairs ministry. Indeed, many people even scholars doubt Kenya had stated foreign policy during Moi’s reign.

\section{REFERENCES}

AJIL no 87 October 1993.

ANC Spokesman, Finance November 1990

BBC News. (11 February 2020). Kenya's Daniel Arap Moi: Thousands pack stadium for funeral.

East, R., \& Thomas, R. J. (2014). Profiles of People in Power: The World's Government Leaders. Routledge. ISBN 9781317639404.

Galloway, et al. (1985). African International Relations. London: Longman.

Hansard (National Assembly Debates) VOL. XXLL 1971.

Hyde in Moore and Rivier. International Law I. 56.

Bryson, H.C. (26 July 2007). Kenya names ex-leader special envoy to Sudan. Reuters.

Jentleson, W.B., \& Paterson, G. (1997). The encyclopedia of U.S foreign relations (volume 3). New York, Oxford University Press.

Jessup Philip C. (1931). The Estrada Doctrine. The American Journal of International Law, 25(4), pp. 719-723. DOI: $10.2307 / 2189922$.

Martin, D., \& Robert, Mc.C. (1991). Cases and Materials on International Law. London: Blackstone.

Kahawatungu. (29 August 2017). Exclusive: Former President Daniel arap Moi Suffering from Dementia.

Malcolm, N.S. (1997). International Law (fourth edition). United Kingdom, Cambridge University Press.

McKenna, A. (Feb 10, 2020). Daniel Arap Moi President of Kenya. https://www.britannica.com/biography/Daniel-arap-Moi

Munene, M. (1997). Historical Antecedents: Changing Ideologies in Kenyan Foreign Policy. Paper presented at USIU-A/DANIDA Symposium, August 27-28.

(1997). Images of Kenya's Foreign Policy in the Media. A paper presented at USIU-AFRICA/DANIDA workshop on the Foreign Policy of Kenya: Issues and Prospects, USIU-A, August 29.

Musambayi, I.C. (1995). The politics of regime consolidation and entrenchment-Moi's foreign policy 1978-1995. French Institute For Research in Africa, Nairobi.

Moi sent off with 19-gun salute - VIDEO, retrieved 12 February 2020

Mphaso. (29 October 2019). All about the condition former President Moi is being treated for in ICU.

Joseph, N. (7 September 2016). No hanging since 1987: Is death penalty still relevant? The Star.

Marc, L. (13 October 2002). Kenya's Leader to Step Down but Not Out. New York Times.

Regional Surveys of the World, Africa South of The Sahara, 29th Edition. (1999). Europa publishers.

Stand ard Digital. (10 February 2020). Raymond: Moi was 105 years old.

Stansifer, C. L. (1967). Application of the Tobar Doctrine to Central America. Americas, 23(3), 251-272.

Satyavrata, R.P. (1964). A textbook of International Law. Bombay: Asia Publishing House.

Society. (8 Augusy 1992). Nyamora Communications Limited.

Talmon, S. (1988). Recognition of governments in international Law: with particular reference to governments in exile. Oxford: Clarendon Press.

Taylor, C. (1994). Multiculturalism: Examining the politics of Recognition (et al). Princeton University.

The Guardian. (30 December 2002). Kibaki sworn in as Kenyan president.

David, T., \& Charles, H. (1998). Multi-party Politics in Kenya: The Kenyatta \& Moi States \& the Triumph of the System in the 1992 Election. James Currey Publishers. ISBN 9780852558041.

Weekly Review (Nairobi). (February 18, 1983). p. 4.

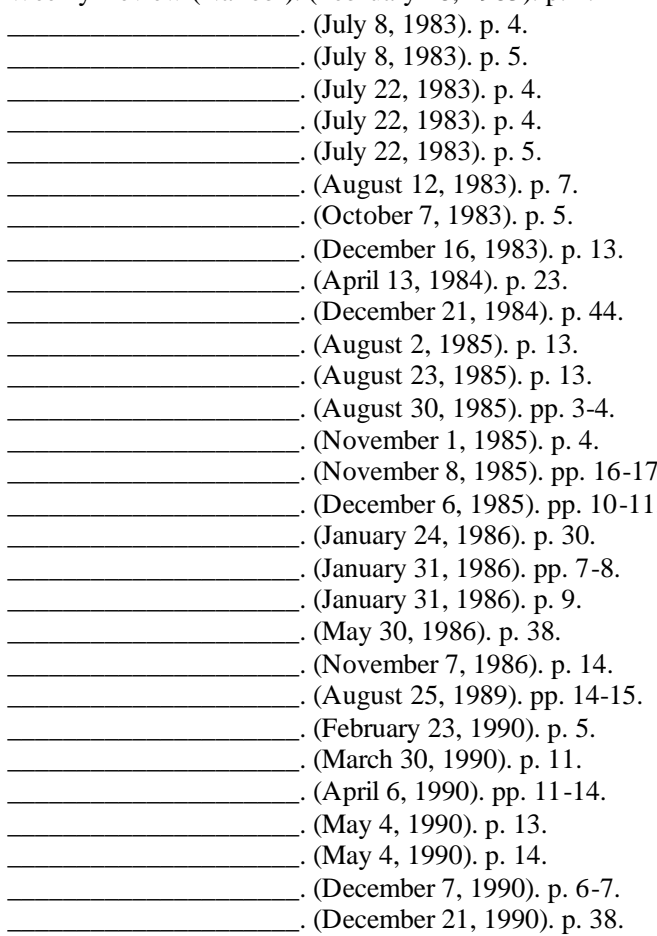


(June 1991)

(May 7, 1993). p. 21

(April 22, 1994). p. 34.

(May 6, 1994). pp. 31-35.

(May 13, 1994). p. 30

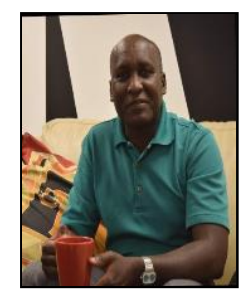

Danvas Ogeto Mabeya was born in Kisii, Kenya. Mabeya graduated with a doctorate degree in Sociology from Kansas State University in 2011. He also has a MA degree in Political Science from the same university as well as a MA in International Relations from United States International University-Africa (U.S.I.U-A). His undergraduate work in International Relations was also completed at United States International UniversityAfrica (U.S.I.U-A) where he obtained a Bachelor of Arts degree.

He has a keen research interest in immigrants/refugees from Eastern Africa which stems from his work with the United Nations High Commission for Refugees (UNHCR) as a research intern from 1998 to 2000 at Dadaab refugee camps in Kenya. Mabey a has also worked with the United Nations Educational Scientific and Cultural Organization (UNESCO - Kenya) in 1997 assisting in coordinating Somalia-PEER-programs for educational and emergencies in the Horn of Africa.

Mabeya has been associated and teaching undergraduate courses in Sociology and Anthropology at Southeast Community College (SCC) since 2013 and enjoys teaching diversity. He has published journal articles and is also a reviewer of several peer reviewed journals. He is currently a board member of the Lincoln Council for International Visitors (LCIV) and was the interim Executive Director of Midwestern African Museum of Art, Culture and Resource Center (MAMA) 2017-2020. 